\title{
PELESTARIAN ASPEK SPIRITUAL SANTRI DI MADRASAH DINIYAH NURUL ULUM PANDANSARI SENDURO LUMAJANG
}

\author{
Haidar Idris \\ Institut Agama Islam Syarifuddin Lumajang, Indonesia \\ E-mail: haidaridris8@gmail.com \\ Miftahul Ulum \\ Institut Agama Islam Syarifuddin Lumajang, Indonesia \\ E-mail: miftahululum.0791@gmail.com
}

\begin{abstract}
Abstrak: Artikel ini ingin melihat madrasah diniyah sebagai salah satu lembaga yang mempertahankan ukhuwah keislaman dan tradisi yang cukup kuat dalam menghadapi tantangan era modernisasi dan globalisasi, hal ini dapat dibuktikan dengan keberhasilan madrasah dalam mencetak kualitas santri yang mapan secara spiritual dan ahklaq mulia. Bahkan madrasah diniyah belakangan dicap memiliki nilai-nilai spiritualitas yang mampu sustainable. Penelitian ini menggunakan metode field research. Penelitian dilakukan di bulan Maret-Mei 2018. Kesimpulan dari penelitian ini adalah penerapan aspek spiritual yang dilakukan di madrasah diniyah Nurul Ulum Pandansari Senduro Lumajang adalah dengan mempertahankan Kurikulum klasik di madrasah itu, penerapan aspek ini tidak hanya kepada santrinya, melainkan kepada seluruh tenaga pengajar. Selain itu, kurikulum pelajaran aqidah dan akhlaq selalu diutamakan dari pada mata pelajaran lain. Mata pelajaran ini dianggap sebagai mata pelajaran pokok dalam mendukung proses implementasinya di lapangan. Proses pembelajarannya pun tidak hanya transfer of knowledge seperti pada umumnya, melainkan melibatkan dua aspek pokok, yakni dhohiriyah (baca: luar) dan bathiniyah (baca: dalam).
\end{abstract}

Kata Kunci: Aspek Spiritual, Santri, Madrasah Diniyah

\section{Pendahuluan}

Hingga hari ini, madrasah diniyah adalah salah satu lembaga pendidikan agama yang masih konsisten mempertahankan tradisi dan nilai keislaman yang cukup kuat terutama dalam menghadapi tantangan era modernisasi dan globalisasi. Hal ini dibuktikan dengan berhasilnya madrasah dalam mencetak kualitas santri yang mapan, sehingga santri tersebut menjadi manusia yang mempertahankan agama Islam, khususnya aspek ahklaq mulia.

\footnotetext{
1 Ary Ginanjar Agustian, Rahasia Sukeses Membangun Kecerdasan Emosi dan Spiritual ESQ Emotional Spiritual Quotient Berdasarkan 6 Rukun Iman dan 5 Rukun Islam (Jakarta: Arga Wijaya Persada, 2001), xxxix. dalam buku ini dijelaskan riset ahli syaraf Australia Wolf Singer pada era 1990-an atas The Binding Problem, yang menunjukkan ada proses syaraf dalam otak manusia yang terkonsentrasi pada usaha yang mempersatukan dan memberi makna dalam 
Spiritual merupakan aspek yang paling minim diperbincangkan. Selain karena keterbatasan sumber, terutama sumber daya manusia, aspek spiritualitas sangat sulit diukur dan ditelaah secara empiris, padahal syarat ilmu yang diterima sebagai ilmu ilmiah harus memiliki karakteristik empiris dan terukur. Selama ini proses pendidikan Islam bergerak dari interaksi antara murid, guru, meteri danlingkungannya, ${ }^{2}$ padahal pada hakikatnya dalam pendidikan seorang pendidik (guru) harus mampu mengoptimalkan IQ, EQ dan SQ yang dimiliki agar nantinya mampu melahirkan para generasi yang juga memiliki IQ, EQ dan SQ yang baik. Dalam perspektif yang umum, setiaporang mampu memiliki kecerdasan emosional dan kecerdasan spiritual. Ini berarti, berfikir adalah kerja dari otak, tepatnya otak kiri. Merasa adalah kerja dari otak tepatnya otak kanan, mengalami kehadiran Tuhan adalah kerja dari otak dan mengalami lobus temporal. Jadi berfikir, merasa, dan mengalami fenomena spiritual, semuanya merupakan kerja dari otak. ESQ-Power adalah kekuatan otak, yakni adanya sinergisitas kecedasan antara fikiran, perasaan, dan pengalaman spiritual. ${ }^{3}$

Kecerdasan spiritual atau lebih sering disingkat dengan SQ adalah satu bentuk kecerdasan untuk menghadapi dan memecahkan persoalan antara makna dan nilai, yaitu kecerdasan untuk menempatkan perilaku dan hidup kita dalam konteks makna yang lebih luas dan kaya, kecerdasan untuk menilai bahwa tindakan atau jalan hidup seseorang lebih bermakna dibandingkan dengan yang lain.

Kecerdasan Spiritual (SQ) merupakan penemuan terkini secara ilmiah yang pertama kali digagas oleh Danah Zohar dan Ian Marshal, melalui riset yang sangat komprehensif bersama timnya yang menemukan eksistensi God Spotdalam otak manusia sebagai pusat spiritual (Spiritual Center) yang terletak diantara jaringan syaraf dan otak. ${ }^{4}$

pengalaman hidup kita. Suatu jaringan syaraf yang secara literal "mengikat" pengalaman kita secara bersama untuk "hidup lebih bermakna". Pada god-spot inilah sebenarnya terdapat fitrah manusia yang terdalam.Untuk menggapai fitrah tersebut manusia harus mempunyai akhlaq yang baik yang juga bisa digapai dengan menggunakan aspek spiritual.

2 Abd. Kadir, “Aspek Pendidikan Spiritual Islam: Implementasi dan Implikasi Pendidikan Islam Terhadap Pengembangan Spiritualitas Keperibadian Muslim”, Disertasi, UIN Sunan Kalijaga, Yogyakarta,2007, 1.

${ }^{3}$ Muhammad Muhyidin, Manajemen ESQ Power (Yogyakarta: Diva Press, 2007), 76.

${ }^{4}$ Danah Zohar dan Ian Marshal, SQ memanfaatkan Kecerdasan Spiritual dalam berfikir Integralistik dan Holistik untuk. Memaknai Kehidupan ,cet IV (Bandung: Mizan, 2001), 4. 
Kecerdasan SQ inilah yang menurut Ary Ginanjar adalah kemampuan untuk memberi makna kehidupan dan makna spiritual terhadap pemikiran, prilaku dan kegiatan sehari-hari, serta mampu mensinergikan IQ,EQ,SQ secara komperhensif, sehinga segala perbuatannya semata-mata hanya karena Allah. Ciri-ciri kecerdasan spiritual ini adalah senang berbuat baik, menolong, memiliki empati yang besar, mampu memaafkan tanpa syarat, mampu memilih kebahagiaan, mampu berpikir secara luas, memiliki selera humor dalam kehidupan dan merasa perlu berkontribusi dalam kehidupan manusia, yang semuanya ditujukan hanya kepada Allah SWT.

Berkaitan dengan teori di atas, maka ditemukan titik temu antara kecerdasan spiritual (SQ) yang merumuskan persoalan makna dan nilai untuk mencapai hidup yang lebih bermakna dengan konsep taqwa yang mengarahkan manusia untuk menemukan hidup yang sesungguhnya (the real meaning of life) melalui jalan mendekatkan diri kepada Tuhan, dan selalu mengingatnya. ${ }^{5}$

Akhir-akhir ini betapa banyak ahli kesehatan biologis (baca: dokter), ahli kesehatan psikologis (psikolog), dan ahli kesehatan sosial (sosiolog), tetapi kita merasa kesulitan mencari ahli kesehatan spiritual. Kalau ditemukan ahli spiritual yang lazim disebut dengan 'guru spiritual itupun tidak dapat disejajarkan dengan dokter, psikolog dan sosiolog, tetapi lebih dipahami sebagai 'dukun' yang paradigma keilmuannya dianggap aneh dan 'nyeleneh.' Karenanya, pendekatan spiritual dalam kesehatan menjadi area yang 'liar', yang objek formal dan materialnya tidak baku, bahkan siapapun dengan latar belakang apapun merasa expert membahasnya. Daniel Goleman mengemukakan bahwa kecerdasan intelektual hanya menyumbang 20\% dari keberhasilan, dan 80\% lagi ditentukan oleh faktor-faktor lain termasuk apa yang saya namakan dengan kecerdasan emosional. ${ }^{6}$ Kecerdasan emosional ini tidak akan berjalan dengan baik tanpa adanya keseimbangan dengan kecerdasan spiritual.

Kecerdasan spiritul adalah kecerdasan yang memang perlu dipertahankan oleh lembaga pendidikan manapun, termasuk madrasah diniyah, karena pada saat ini pusat eksistensi yang dimiliki manusia semakin terkikis. Penerapan metode spiritual adalah

\footnotetext{
5 Sulaiman Al-Kumayyi, Menuju hidup Sukses Kontribusi Spiritual Intelektual AA Gym dan Arifin Ilham (Semarang: Pustaka Nuun, 2005), 165.

${ }^{6}$ Patricia Patton. Emotional Quotient (EQ), Pengembangan Sukses Lebih Bermakna (tp: Mitra Media, 2002), 1.

98 | Tarbiyatuna: Jurnal Pendidikan Islam; Volume 12, Nomor 1, Februari 2019 p-ISSN: 2085-6539; e-ISSN: 2242-4579
} 
penerapan komparatif secara jitu, dengan memperhatikan struktur dari tradisi Islam dan tradisi timur lainya. Penerapan ini akan menunjukkan pula bahwa diantara semua itu, ajaran- ajaran Islam yang bersifat metafisis dan mistis, yang terutama sekali dijumpai di dalam sufisme, itulah yang paling dapat memberikan jawaban-jawaban terhadap kebutuhan-kebutuhan intelektual yang paling mendesak pada saat ini, dan bahwa hal-hal spiritual yang terkandung di dalam sufisme itulah yang lebih dapat memuaskan dahaga manusia-manusia yang mencari Allah. ${ }^{7}$

Atas dasar hal tersebut, penulis mendapati Madrasah Diniyah di Pandansari Senduro Lumajang yang masih 'setia' mengimplementasikan aspek spiritual dan bahkan dijadikan sebagai kurikulum pokok.

\section{Spiritual dalam KajianTeoritik}

Menurut Imam al-Ghazali dalam kitabnya Ihya' Ulumuddin, aspek spiritual ini yang oleh beberapa ilmuan disebut ruh atau bagian dari hati. ${ }^{8}$ Dalam hal ini Imam Ghazali memberi wacana empat ${ }^{9}$ poin yang harus dipahami saat hendak membicarakan spiritual.

Dimensi-dimensi dasar manusia yakni dimensi fisik (jasadiyab), psikis (ruhaniyah), dan sosial (ijtima'iyah): ${ }^{10}$

1. Dimensi fisik atau badan ini adalah dimensi yang paling nyata dalam diri manusia, dalam arti dapat dilihat, diraba, dipegang. Dari keseluruhan aspek sebagai dimensi yang membentuk diri manusia, aspek inilah yang merupakan unsur yang paling rill di mata kita.

2. Dimensi psikis atau jiwa. Dimensi ini merupakan dimensi dasar kedua dari manusia, yang hakekatnya adalah aspek kejiwaan yang meliputi pemikiran,

\footnotetext{
7 Seyyed Hossein Nasr,Islam dan Nestapa Manusia Modern (Bandung: Pustaka, 1975 ), 78.

8 Abdul Mujib, Rub dan Psikology (Jakarta: Prenada Media, 2006), 68-73. Ia berbeda pendapat namun yang namanya spiritual tetaplah dinamakan ruh. Imam Ghazali dalam kitabnya berpendapat bahwa ruh ini adalah bagian dari hati, namun menurut abdul mujib Berdasarkan studi literaturnya mengkategorikan pengertian ruh adalah sebagai padanan spirit dalam empat kelompok, yaitu 1. Materialisme murni hal ini ruh merupakan materi. 2. Spiritual materialisme ruh bersifat spiritual sekalipun digambarkan dalam bentuk material. 3. Spiritualisme murni dalam hal ini ruh merupakan subtansi ruhani yang tidak terkait dengan sifat sifat materi dan 4. Gabungan antara materialisme dan spirituaisme yakni ruh adalah merupakan kesatuan jiwa an-nafs dan badan.

9 Imam Ghazali, Ringkeasan Ibya' Ulumuddin, 296 - 298. Yaitu hati, roh, nafsu dan akal yang mana empat aspek tersebut harus saling menyeimbangkan satu sama yang lain, karena ke empatnya saling membutuhkan

10 Eni Purwati, dkek, Pendidikan Karakter: Menjadi Berkarakter Muslim - Muslimah Indonesia (Surabaya: Kopertais Wilaya IV, 2012), 64
} 
inteligensi, hal hal yang berkaitan dengan emosi, unsur-unsur kerohanian, atau hal-hal yang mencakup unsur batiniyah lainya. Semuanya merupakan unsur dalam dari manusia. Dimensi psikis manusia terdiri atas beberapa unsur penting yang tampil dalam bentuk kecerdasan, dengan rincian sebagai berikut:

a. Kecerdasan Intelektual $(I Q=$ Intelectual Quotient $)$.

b. Kecerdasan Emosional (EQ= Emotional Quotient). ${ }^{11}$

c. Kecerdasan Spiritual (SQ= Spiritual Quotient).

Bagi manusia kecerdasan sepiritual merupakan pikiran yang terilhami, sebagai pengetahuan akan kebenaran yang paling dalam. Kecerdasan spiritual dapat juga dipahami sebagai kekuatan instuisi yang tajam, untuk melihat kebenaran paling dalam, yang membatasi kemampuan intelektual semata. Kecerdasan ini kemudian masuk ke kesadaran, dan akhirnya masuk ke penghayatan hidup, yang akan membuat orang hidup lebih toleran, terbuka dan jujur, berlaku adil dan penuh cinta. Dari kecerdasan bergerak menuju ke kearifan, dan meraih kebahagiaan spiritual atau spiritual happines. Kecerdasan spiritual berada di seputar jiwa, dan bersifat mempersatukan (unitif).

3. Dimensi sosial. Hakekat manusia adalah sebagai mahkluk sosial, kebutuhankebutuhan yang berkaitan dengan dimensi sosial manusia meliputi: kebutuhan dan penerimaan, dicintai dan mencintai, pengakuan dan persahabatan serta segala bentuk hubungan sosial lainnya.

Kecerdasan spiritual (SQ) adalah sarana yang dapat kita gunakan untuk bergerak yang satu ke yang lain, sarana yang dapat kita gunakan untuk menyembuhkan diri kita sendiri. Dalam bahasa Inggris, kendaraan kecerdasan spiritual, secara harfiah berarti "recollect" (mengumpulkan kembali), "pick up" (mengambil), atau "qather" (mengumpulkan) kepingan-kepingan diri kita yang terbelah. ${ }^{12}$

\footnotetext{
11 Berawal dari hasil penelitian yang menunjukkan bahwa ada cukup banyak orang yang ber- IQ tinggi, namun gagal dalam hidupnya, sementara banyak orang yang IQ- nya sedang-sedang saja, bahkan rendah, menjadi orang yang sukses. Dari hasil penelitiannya selama bertahun-tahun, akhirnya Daniel Goleman memastikan bahwa ada faktor lain yang lebih menjamin orang akan sukses dalam hidupnya, yakni “ kecerdasan emosional” (EQ). Daniel Goleman, Kecerdasan Emosional. Menggapai Lebih Penting daripada IQ (Judul Asli: Emotional Intelligence), Alih Bahasa: T. Hermaya(Jakarta: PT. Gramedia Utama), 17.

12 Danah Zohar dan Ian Marshal. SQ kecerdasan Spritual (Jakarta: Mizan Pustaka, 2007), 161.
} 
SQ adalah landasan yang diperlukan untuk memfungsikan IQ dan EQ secra efektif. SQ merupakan kecerdasan tertinggi manusia. Dalam ESQ kecerdasan spiritual adalah kemampuan untuk memberi makna spiritual terhadap pemikiran, prilaku dan kegiatan, serta mampu menyinergikan IQ, EQ dan SQ secara komprehenshif dan transedental. ${ }^{13}$

Dalam krisis spiritual, seluruh makna dan mungkin nilai kita jadi dipertanyakan. Kita mungkin menjadi tertekan atau depresi, berpaling ke obat-obatan atau alkohol untuk mendapatkan tempat pelarian sementara, menjadi lesu atau terganggu, atau bahkan jatuh ke dalam kegilaan. Krisis semacam itu selalu menyakitkan, namun jika dihadapi dengan berani dan dimnmfaatkan, dia dapat memberikan kesempatan untuk meningat dan selanjutnya memperbaiki serta mengubah diri. ${ }^{14}$

Sementara itu menurut Kalil Khawari, kecerdasan spiritual merupakan fakultas dari dimensi non material kita atau ruh manusia. Inilah intan yang belum terasah yang kita semua memilikinya. Kita semua harus mengenalinya seperti apa adanya, menggosoknya sehingga berkilap dengan tekat yang besar dan menggunakannya untuk memperoleh kebahagiaan abadi. Seperti dua bentuk kecerdasan lainnya (intelektual dan emosi), kecerdasan spiritual dapat ditingkatkan dan diturunkan. Akan tetapi, kemampuannya untuk ditingkatkan tampaknya tidak terbatas. $^{15}$

Dengan nada yang sama Muhammad Zuhri memberikan definisi, kecerdasan spiritual adalah kecerdasan manusia yang digunakan untuk berhubungan dengan Tuhan. Potensi kecerdasan spiritual setiap orang sangat besar dan tidak dibatasi oleh faktor keturunan, lingkungan atau materi lainnya. ${ }^{16}$

Sedangkan menurut Ary Ginanjar, kecerdasan spiritual adalah kemampuan seseorang dalam memberi makna ibadah terhadap setiap perilaku dan kegiatan, melalui langkah-langkah dan pemikiran yang bersifat fitrah menuju manusia seutuhnya (hanif), dan memiliki pola pemikiran tauhid (integralistik), serta berprinsip

13 Zohar dan Marshal. SQ, 14

14 Zohar dan Marshal. SQ, 163

15 Zohar dan Marshal. SQ, 27

16 Agus Nggermanto, Quantum Quotient: Kecerdasan Quantum (Bandung: Multi Intelligence Centre, 2001), 117. 
"hanya karena Allah". Sebagaimana hadits Rasullullah SAW "Sesungguhnya orang cerdas adalah orang yang senantiasa mendekatkan diri kepada Allah dan dia beramal untuk sesudah mati” (Hadits). Lebih lanjut Ary Ginanjar mengemukakan kecerdasan spiritual merupakan pencerminan dari rukun iman yang harus di imani oleh setiap orang yang mengaku beragama Islam. ${ }^{17}$

Kecerdasan Spritual (SQ) adalah kecerdasan yang bertumpu pada bagian dalam diri kita yang berhubungan dengan kearifan di luar ego atau jiwa sadar. Hal utama dalam kecerdasan spiritual adalah pengenalan akan kesejatian diri manusia. Kecerdasan spiritual bukan sebuah ajaran teologis, kecerdasan ini secara tidak langsung berkaitan dengan agama. Kecerdasan spiritual itu mengarahkan manusia pada pencarian hakikat kemanusiannya. Hakikat manusia dapat ditemukan dalam perjumpaan atau saat berkomunikasi antara manusia dengan Allah SWT (misalnya pada saat shalat). Oleh karena itu, ada yang berpandangan bahwa kecerdasan spiritual (SQ) adalah kecerdasan manusia yang digunakan untuk berhubungan dengan Tuhan. Asumsinya adalah jika seseorang hubungan dengan Tuhannya baik, maka bisa dipastikan hubungan dengan sesama manusiapun akan baik pula.

SQ memungkinkan manusia menjadi kreatif, mengubah aturan dan situasi. SQ memberikan kemampuan yang membedakan, SQ memberi kita rasa moral, kemampuan menyesuaikan aturan yang kaku dibarengi dengan pemahaman dan cinta serta kemampuan yang setara untuk melihat kapan cinta dan pemahaman sampai kepada batasnya. Kita menggunakan SQ untuk bergulat dengan ihwal baik dan jahat, serta untuk membayangkan kemungkinan yang belum terwujud untuk bermimpi, bercita-cita, dan mengangkat diri kita dari kerendahan. ${ }^{18}$

Menyempurnakan pendapat di atas, Hafiduddin menuliskan bahwa spiritual lebih kepada pemaknaan manusia secara lebih mendalam seorang ilmuan yang mampu memahami rahasia alam, namun ia tidak mengenal tuhannya terhadap esensi penciptaannya di atas dunia yang fana ini. Di sini spiritual dikaitkan dengan nilai-nilai

17 Ary Ginanjar Agustian, Emotional Spiritual Quotient (ESQ) (Jakarta: Arga Publishing, 2001), 57.

${ }^{18}$ Daniel Goleman, Emotional Intelligence: Mengapa EQ Lebih Penting daripada IQ Jakarta: Gramedia Pustaka Utama, 2003), 5.

102 | Tarbiyatuna: Jurnal Pendidikan Islam; Volume 12, Nomor 1, Februari 2019 p-ISSN: 2085-6539; e-ISSN: 2242-4579 
agama. ${ }^{19}$ Bagi Islam bagaimana seorang hamba memahami esensi penciptaannya dan kemudian ia berusaha menjalankannya sebagai wujud menjalankan perintah yang menciptakannya.

Dalam Al qur'an Allah SWT telah berfirman bahwa :

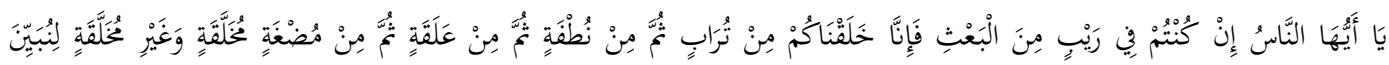

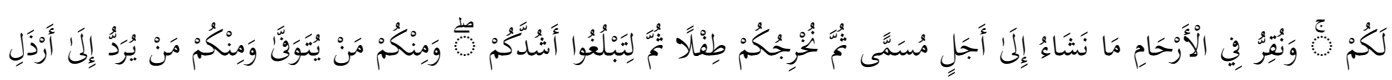

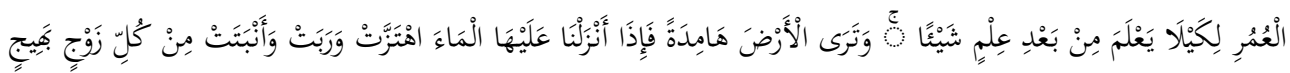

Artinya: Hai manusia, jika kamu dalam keraguan tentang kebangkitan (dari kubur), maka (ketahuilah) sesunggubnya Kami telah menjadikan kamu dari tanah, kemudian dari setetes mani, kemudian dari segumpal darah, kemudian dari segumpal daging yang sempurna kejadiannya dan yang tidak sempurna, agar Kami jelaskan kepada kamu dan Kami tetapkan dalam rahim, apa yang Kami kehendaki sampai waktu yang sudah ditentukan, kemudian Kami keluarkan kamu sebagai bayi, kemudian (dengan berangsurangsur) kamu sampailah kepada kedewasaan, dan di antara kamu ada yang diwafatkan dan (adapula) di antara kamu yang dipanjangkean umurnya sampai pikun, supaya dia tidak mengetahui lagi sesuatupun yang dabulunya telah diketabuinya. Dan kamu lihat bumi ini kering, kemudian apabila telah Kami turunkan air di atasnya, hiduplah bumi itu dan suburlah dan menumbubkan berbagai macam tumbub-tumbuban yang indah. (QS AlHajj: 5). ${ }^{20}$

Allah berfirman:

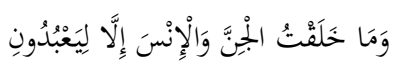

Artinya: Dan aku tidak menciptakan jin dan manusia melainkan supaya mereka mengabdi kepada-Ku. (QS Az-Zariyat: 56). ${ }^{21}$

Berdasarkan firman Allah SWT dalam Al qur'an di atas, spiritual bagi seorang muslim adalah penyerahan diri sepenuhnya hanya untuk yang menciptakannya. Spiritual menjadikan Allah SWT sebagai tujuan akhir kehidupannya, sehingga apapun yang dia lakukan di atas permukaan bumi ini semuanya merupakan wahana untuk pengabdian kepada Allah SWT. Makanya dalam setiap kerja yang dilakukannya, semua dianggap sebagai ibadah kepada Allah SW'T. Dalam Al qur'an Allah SW'T menyebutkan :

\footnotetext{
${ }^{19}$ Hafidhuddin, dkk, Management Syari'ah Dalam Praktek (Jakarta: Gema Insani. 2003), th. ${ }^{20}$ Muhammad Junus, Terjemah Al-Quran Al-karim (bandung: Al-Ma'arif, 1996), cet 10, 300 ${ }^{21}$ Junus, Terjemah Al-Quran,472.
} 


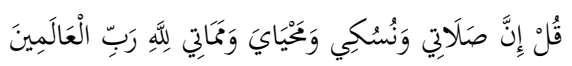

Artinya: Katakanlah: Sesunggubnya sholatku, ibadatku, bidupku dan matiku hanyalah untuk. Allah, Tuhan semesta alam. (QS Al-An'am:162). ${ }^{22}$

Selain itu seorang muslim meyakini bahwa apapun yang dilakukan akan dibalas oleh Allah SW'T, sebagaimana firmanNya:

Artinya: Barang siapa yang mengerjakan kebaikan seberat dzarrahpun, niscaya Dia akan melihat (balasan) Nya. Dan Barangsiapa yang mengerjakan kejahatan sebesar dzarrahpun, niscaya Dia akan melihat (balasan) Nya pula.(QS Az- Zalzalab: 7-8). ${ }^{23}$

Penghambaan diri kepada Allah SWT bagi seorang muslim sebetulnya merupakan bentuk memegang janji kepada Allah SWT. Dalam Al qur'an telah dijelaskan bahwa sebelum manusia dan bumi diciptakan, ruh manusia telah mengadakan perjanjian dengan Tuhannya. Tuhan bertanya kepada jiwa manusia "Bukankah Aku Tubanmu?" lalu ruh manusia menjawab "Ya, kami bersaksi, Engkau Tuhan kami''(QS al-A'raf: 172)

Bukti perjanjian ini menurut Dryarkara, adanya suara hati manusia, yaitu suara tuhan yang merekam dalam diri manusia. Sehingga ketika manusia hendak berbuat keburukan, suara hati nurani akan melarangnya, karena Allah SWT tak menghendaki manusia berbuat kemungkaran. Jika manusia tetap mengerjakan keburukan itu, suara hatinya akan menasehati dan akan muncul perasaan menyesalinya. MacScheler mengatakan penyesalan adalah "tanda kembalinya seseorang kepada tuhan", ${ }^{24}$ itulah pengakuan bahwa manusia adalah makhluk spiritual.

Menurut Danah Zohar dan Marshal, tanda-tanda dari kecerdasan spiritual yang telah berkembang dengan baik adalah sebagai berikut:

1. Kemampuan bersikap fleksibel (adaptif secara spontan dan aktif)

2. Kemampuan untuk menghadapi dan memanfaatkan penderitaan untuk menghadapi dan melampaui rasa sakit.

3. Kualitas hidup yang di ilhami oleh kualitas visi dan nilai

4. Keengganan untuk menyebabkan kerugian yang tidak perlu.

22Junus, Terjemah Al-Quran, 136.

23Junus, Terjemah Al-Quran, 539.

${ }^{24}$ Agustian, Emotional Spiritual Quotient, 47.

104 | Tarbiyatuna: Jurnal Pendidikan Islam; Volume 12, Nomor 1, Februari 2019 p-ISSN: 2085-6539; e-ISSN: 2242-4579 
5. Kecenderungan untuk melihat keterkaitan antara berbagai hal (berpandangan holistik).

6. Kecenderungan nyata untuk bertanya mengapa atau bagaimana jika mencari jawaban-jawaban yang mendasar. Menjadi apa yang disebut para psikolog sebagai bidang mandiri yaitu memiliki kemudahan untuk bekerja melawan konveksi. ${ }^{25}$

Perilaku manusia dalam perspektif spiritual qoutient merupakan hasil tarik menarik antara energi positif dan energi negatif. ${ }^{26}$ Energi positif berupa dorongan spiritual dan nilai-nilai etis religius (taubid), sedangkan energi negatif berupa nilai-nilai material (thoghut). Nilai - nilai spiritual dan etika religius berfungsi sebagai sarana pemurnian, pensucian dan pembangkitan nilai - nilai kemanusiaan yang sejati (hati nurani).$^{27}$

Menurut Profesor Khalil A. Khavari, ada beberapa aspek yang menjadi dasar kecerdasan spiritual, diantaranya:

1. Sudut pandang spiritual keagamaan, artinya semakin harmonis relasi spiritualkeagamaan kita kehadirat Tuhan, semakin tinggi pula tingkat dan kualitas kecerdasan spiritual kita.

2. Sudut pandang relasi social keagamaan, artinya kecerdasan spiritual harus direfleksikan pada sikap-sikap sosial yang menekankan segi kebersamaan dan kesejahteraan sosial.

3. Sudut pandang etika sosial, semakin beradab etika sosial manusia semakin berkualitas kecerdasan spiritualnya.

\footnotetext{
25Danah Zohar dan Ian Marshal, SQ, Kecerdasan Spiritual (Bandung : Mizan, 2007), 14.

${ }^{26}$ Maka allah mengilhamkan pada jiwa itu (jalan) kefasikan dan ketaqwaannya "Q.S 91 / Asy- Syams: 8. AlGhazali berpendapat bahwa dalam hati manusia terdapat pasukan-pasukan yang secara umum dibagi menjadi dua: pasukan dorongan kebaikan yang disimbolkan dengan pasukan malaikat dan pasukan dorongan jahat yang disimbolkan dengan pasukan setan. Perilaku manusia ditentukan oleh pasukan mana yang mengendalikan hati manusia itu. Lihat, Imam Ghazali, Ibya' Ulumuddin Juz III, terj. NurhicmahJakarta” Tintamas, 1984, 82 dst. Ary Ginanjar Agustian dalam pembahasannya tentang meta kecerdasan berpendapat bahwa dalam diri manusia itu ada dua kekuatan orientasi yaitu orientasi spiritualisme (tauhid) dan orientasi materialisme (thoghut). Dengan orientasi spiritualisme (tauhid) komponen-komponen dalam kepribadian manusia (IQ, EQ dan SQ) dapat terintegrasi dan bekerja secara maksimal sehingga melahirkan meta kecerdasan atau energi positif yang luar biasa. Sebaliknya, orientasi materialisme (thogbut) akan menyebabkan IQ, EQ dan SQ terpisah dan melahirkan energi negatif yang luar biasa juga. Lihat, Ary Ginanjar Agustian, ESQ Power Sebuab Inner Journey Melalui Ibsan (Jakarta: Arga, 2003), $217-220$.

${ }^{27}$ Tobroni, The Spiritual Leadership Pengefektifan Organisasi Noble Industry Melauli Prisip-prinsip Spiritual Etis (Malang: UMM Pres, 2005), 10.
} 
Menurut Al-Ghazālī dalam Al-Munqiz min al-Dhaläl, bahwa sulük atau proses transendensi dapat ditempuh melalui tiga langkah; (1) mensucikan kalbu secara total dari selain Allah (tathhìr al-galb bi al-kullīyah 'amma siwā Alläh). (2) melakukan zikir kepada Allah secara total (al-istighrāq bi dæi ker Alläh), (3) lebur dalam zat Allah (al-fana fi Allāh). ${ }^{28}$

Al-Ghazālī juga mengemukakan sejumlah komponen bagi pedidikan spiritual, seperti yang terdapat pada setiap rub' dari kitab Ihyā 'Ulūm al-Dīn. Komponen tersebut terdiri atas tiga komponen dasar, yaitu al-ibādah, al'adat (mu'ämalah), dan akbläke(al-mublikeàt dan al-munjiät). Rub' al-'ibādah terdiri sepuluh komponen yakni: ilmu, akidah, thaharah, shalat, zakat, puasa, haji, tilawah al-Qur'an, zikir dan doa,

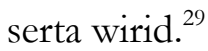

Rub' al-'Adat terdiri dari sepuluh komponen yaitu: makan, nikah, usaha dan mencari penghidupan, halal dan haram, kekeluargaan, persaudaraan, persahabatan dan pergaulan, 'u§lah, safar, al-sam $\vec{a}$, amar makruf dan nahi munkar, serta adab kehidupan dan akhlak kenabian. ${ }^{30}$

Rub' akbläk berupa sejumlah sifat-sifat yang harus dibersihkan dari jiwa (almublikeät) dan sejumlah sifat yang harus dimiliki jiwa (al-munjiyät). Sifat al-mublikēt antara lain syahwat perut dan seks, bahaya lidah, marah, iri, dengki, cinta dunia, cinta harta, bakhil, jāh, ria, ujub, takabur, dan ghurūr. Sedangkan komponen al-munjizăt berupa tobat dan tawakal, kasih sayang, rindu, intim dan rida, niat ikhlas dan benar, al-murāqabah dan al-muhāsabah, tafakkur, serta mengingat mati. ${ }^{31}$ Komponenkomponen ibadah bertujuan membentuk keharmonisan hubungan manusia dengan Allah, komponen-komponen 'adat (mu'amalah) bertujuan membentuk keharmonisan hubungan manusia dengan sesamanya, dan komponen-komponen akhlak bertujuan membentuk keharmonisan hubungan manusia dengan dirinya sendiri.

\footnotetext{
${ }^{28}$ Lihat Al-Ghazālī, Al-Munqiz min al-Dhaläl, (Kairo: t.p., 1316H), h. 54. Dalam tasawuf, perjalanan dan kemajuan kehidupan spiritual seorang sufi (penempuh jalan menuju Tuhan) disebut sulük. Kendati secara literal makna sulük. adalah menempuh jalan yang berkonotasi tindakan fisik dan bisa dipandang sebagai gerakan yang berdimensi ruang, namun dalam istilah teknis tasawuf, sulük adalah perjalanan dan perkembangan spiritual yang tidak berada pada dimensi ruang. Sulük sesungguhnya merupakan proses transmutasi manusia dari alam eksoteris ke dalam alam esoteris untuk menuju proses transendensi kepada Tuhan.

${ }^{29}$ Lihat Abū Hāmid al-Ghazālī, Ihya ' 'Ulüm al-Dìn (Beirut: Dār al-Ma’rifah, t.t.), Juz I, 89.

${ }^{30}$ Lihat Abū Hāmid al-Ghazā̄ī, Ihyyà, Juz II, 3-210.

${ }^{31}$ Lihat Abū Hāmid al-Ghazālī, Ibya $\vec{a}$, Juz III, 121-367; Juz IV, 59-409.
}

106 | Tarbiyatuna: Jurnal Pendidikan Islam; Volume 12, Nomor 1, Februari 2019 p-ISSN: 2085-6539; e-ISSN: 2242-4579 
Pendidikan spiritual, didukung oleh pendidikan akhlak dan disempurnakan dengan pendidikan sosial, merupakan tiga tahapan dalam pembinaan pendidikan Islam. Upaya yang terpenting dalam menyinari bangunan ini adalah senantiasa mengingat Allah (driker Alläh) dan memuji-Nya, membaca al-Qur'an, istiqamah dalam ibadah, dan berdoa dengan merendahkan diri (tadarru').

Spiritual dapat dipengaruhi oleh banyak faktor. Melalui teori "the diamond of self and other" coyte mengemukakan empat faktor yang mempengaruhi spiritual individu. Empat faktor itu sebagaimana pada gambar di bawah ini: ${ }^{32}$

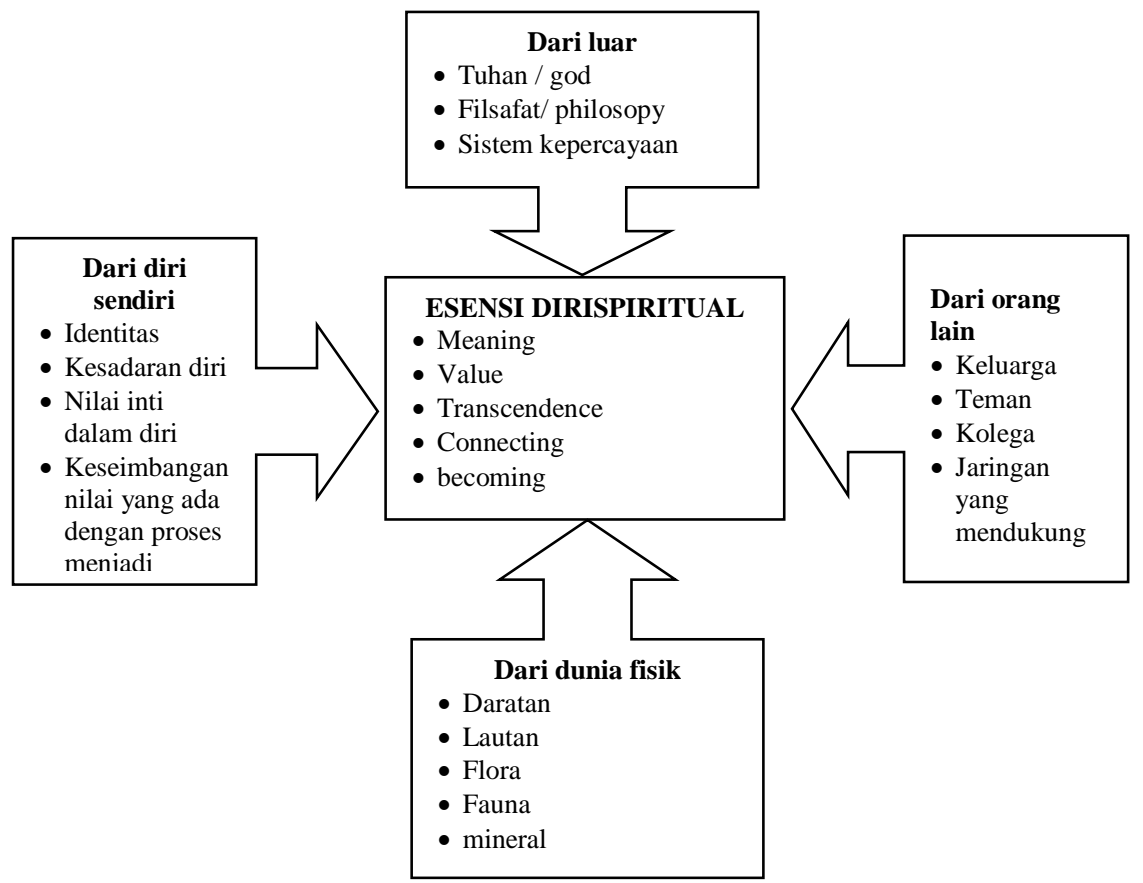

Keempat faktor di atas memiliki peluang yang sama dalam proses mempengaruhi diri manusia. Dalam islam justru faktor yang paling menentukan adalah hidayah Allah. Banyak orang mencoba masuk dalam dunia spiritual, namun ia

${ }^{32}$ Coyte M.E, "Spirituality values and mental healt jewels for the journey", dalam Implementasi Psiko-Spiritual ed. Abdul Mujib, London: Jessica Kingsley Publishers, 2007, 24 
baru menemukan kulitnya dan merasa puas. Mereka memperole keramat yang dinilai sebagai anugrah, padahal itu semua merupakan penghalang (hijab) yang menghambat perolehan puncak spiritual.

Menurut Sinetar faktor-faktor yang mendukung kecerdasan spiritual otoritas intuitif, yaitu kejujuran, keadilan, kesamaan perlakuan terhadap semua orang dan mempunyai faktor yang mendorong (motivasi) kecerdasan spiritual. Suatu dorongan yang disertai oleh pandangan luas tentang tuntutan hidup dan komitmen untuk memenuhinya. ${ }^{33}$

Sedangkan menurut Agustian adalah inner value (nilai-nilai spiritual dari dalam) yang berasal dari dalam diri (suara hati), seperti transparency (keterbukaan), responsibilities (tanggung jawab), accountabilities (kepercayaan), fairness (keadilan) dan social wareness (kepedulian sosial). Faktor kedua adalah drive yaitu dorongan dan usaha untuk mencapai kebenaran dan kebahagiaan. ${ }^{34}$ Dari pendapat para tokoh tersebut dapat disimpulkan bahwa faktor-faktor kecerdasan spiritual ialah suatu dorongan yang berasal dari dalam diri seseorang untuk mencapai kebenaran dan kebahagiaan.

\section{Perbedaan Religiusitas dan Spiritualitas}

Glock dan Stark mengemukakan religiusitas sebagai komitmen relegius (yang berhubungan dengan agama atau kenyakinan iman). Religius dapat dilihat melalui aktivitas atau perilaku individu yang besangkutan dengan agama atau kenyakinan iman yang dianut. ${ }^{35}$ Religuisitas seringkali diidentikan dengan keberagamaan. Religiusitas diartikan sebagai seberapa jauh pengetahuan, seberapa kokoh keyakinan, seberapa pelaksanaan ibadah dan seberapa dalam penghayatan atas agama yang dianutnya. Bagi seorang muslim, religiusitas dapat diketahui dari seberapa jauh pengetahuan, kenyakinan, pelaksanaan dan penghayatan atas agama Islam. ${ }^{36}$

Dari pengertian di atas maka religiusitas dalam Islam menyangkut lima hal yakni aqidah, ibadah, amal, akhlak (ihsan) dan pengetahuan. Aqidah menyangkut

\footnotetext{
${ }_{33}^{33}$ Sineter, Kecerdasan Spiritual (Bandung: Mizan Pustaka, 2001), 42.

34 Ary Ginanjar Agustian, Rahasia Sukses, 45.

35 http// Religiusitas, all 'Bout Psikologi, Bisnis Online, Aku, and Cinta. Htm. Di akses 18 April 2018 jam $12: 17$ WIB.

36 Fuad Nashori dan Rachmy Diana Muschram, Mengembangkan Kreatifitas dalam Presfektif Psikiologi Islam (Jogjakarta: Menara Kudus: 2002), 71. 
kenyakinan kepada Allah, malaikat, Rasul dan seterusnya. Ibadah meyangkut pelaksanaan hubungan antar manusia dengan Allah, akhlak merujuk pada spontanitas tanggapan atau prilaku seseorang atau rangsangan yang hadir padanya. Sementara ihsan merujuk pada situasi di mana seseorang merasa sangat dekat dengan Allah, ihsan merupakan bagian dari akhlak. Bila akhlak positif seseorang mencapai tingkatan optimal, maka ia memperoleh berbagai pengalaman dan penghayatan keagamaan, itulah ihsan dan merupakan akhlak tingkat tinggi. Selain keempat hal di atas ada lagi yang penting harus di ketahui dalam religiusitas Islam yakni pengetahuan keagamaan seseorang. ${ }^{37}$

Perkembangan berikutnya dalam usaha untuk menguak rahasia kecerdasan manusia adalah berkaitan dengan fitrah manusia sebagai makhluk Tuhan. Kecerdasan intelektual (IQ) dan kecerdasan emosional dipandang masih berdemensi horizontalmaterealistik belaka (manusia sebagai makhluk induvidu dan makhluk sosial) dan belum menyentuh persoalan inti kehidupan yang menyangkut fitrah manusia sebagai makhluk Tuhan (dimensi vertical-spritual). Berangkat dari pandangan bahwa sehebat apapun manusia dengan kecerdasan intelektual maupun kecerdasan emosionalnya pada saat-saat tertentu, melalui pertimbangan fungsi afektif, kognitif, konatifnya manusia akan menyakini dan menerima tanpa keraguan bahwa diluar dirinya ada sesuatu kekuatan yang Maha Agung yang melebihi apapun, termasuk dirinya. Penghayatan seperti itu menurut Zakiah Darajat disebut sebagai pengalaman keagamaan (religious experience).

Brightman menjelaskan bahwa penghayatan keagamaan tidak hanya sampai kepada pengakuan atas keberadaan-Nya, namun juga mengakui-Nya sebagai sumber nilai-nilai luhur yang abadi yang mengatur tata kehidupan alam semesta raya ini. Oleh karena itu, manusia akan tunduk dan berupaya untuk mematuhinya dengan penuh kesadaran dan disertai penyerahan diri dalam bentuk ritual tertentu, baik secara induvidu maupun kolektif, secara simbolik maupun dalam bentuk nyata kehidupan sehari-hari. $^{38}$

\footnotetext{
${ }^{37}$ Nashori dan Muschram, Psikiologi Islam, 72-73.

38 Taufiq Fasiak, Revolusi IQ, EQ, dan SQ antara Neurosains dan Al-Quran (Bandung: Mizan 2002), 17.
} 
Kecerdasan spiritual bukanlah doktrin reliqiusitas yang mengajak manusia untuk cerdas dalam memilih dan memeluk suatu agama yang dianggap benar. Kecerdasan spiritual lebih merupakan sebuah konsep yang berhubungan dengan bagaimana seseorang cerdas dalam mengelolah dan mendayagunakan makna-makna, nilai-nilai, dan kualitas-kualitas spritualitasnya. ${ }^{39}$

Jadi reliqiusitas juga berperan dalam pegendalian kecerdasan emosi seseorang. Dengan tekun beribadah dan beramal saleh seseorang akan mencapai derajat ihsan di mana orang akan merasakan ketenangan jiwa, tidak pemarah dan dengan mudah bisa bersosialisasi dengan masyarakat sehingga tercipta hubungan yang harmonis.

Dengan bekerja sesuai tuntunan agama, maka seseorang akan memperoleh ketenangan yang berimbas pada peningkatan kualitas dan kuantitas pekerjaan yang dikerjakan. Etos kerja, disiplin kerja dan kreatifitas dalam bekerja akan meningkat. Keduanya, yakni religiusitas dan kecerdasan emosional akan berpengaruh terhadap kinerja seseorang.

Dikatakan tanpa adanya pengendalian atau kematangan emosi (EQ) dan keyakinan terhadap Tuhan Maha Esa (keimanan dan ketaqwaan) atau reliqiusitas, sangat sulit bagi seseorang untuk dapat bertahan dalam menghadapi tekanan frustasi, stress, menyelesaikan konflik yang sudah menjadi bagian atau resiko profesi/pekerjaan, dan memikul tanggung jawab serta untuk tidak menyalahgunakan kemampuan dan keahlian yang merupakan amanah yang dimilikinya kepada jalan yang tidak dibenarkan, sehingga akan berpengaruh terhadap hasil kinerja (mutu dan kualitas) atau terjadinya penyimpangan-penyimpangan, kecurangan dan manipulasi terhadap tugas yang diberikan. Karena seseorang yang memiliki pemahaman atau kecerdasan emosional dan tingkat religiusitas yang tinggi akan mampu bertindak atau berprilaku dengan etis dalam pekerjaan dan organisasi. ${ }^{40}$

Berdasarkan penjelasan di atas orang religius adalah orang yang agamis, rajin beribadah, dan terlihat dari penampilannya. Dan orang yang spiritual adalah orang

39 Abdul Mujid dan Yusuf Mudzakir, Nuansa-Nuansa Psikiologi Islam (Jakarta: PT. Raja Grapindo Persada: 2002), 324-325.

${ }^{40}$ Nana Syodih Sukmadinata, Landasan Psikologi Proses Pendidikan (Bandung: PT. Remaja Rosdakarya: 2005), 93.

110 | Tarbiyatuna: Jurnal Pendidikan Islam; Volume 12, Nomor 1, Februari 2019 p-ISSN: 2085-6539; e-ISSN: 2242-4579 
yang baik, bukan hanya dalam menjalankan agama/ibadah saja, tetapi ia baik dimanapun ia berada. Ada 5 perbedaan antara orang yang religius dan spiritual :

1. Orang religius menganggap Tuhan itu ada. Orang spiritual menganggap tuhan itu hadir. Orang yang melakukan perbuatan tidak baik karena menganggap tuhan itu hanya ada, tetapi tidak hadir. Sedangkan orang spiritual berpikir bahwa tuhan itu ada dimanapun dia berada (hadir).

2. Orang religius adalah orang yang merasa paling suci dan paling benar dibandingkan orang lain. Orang spiritual menganggap semua orang setara, mengakui kelebihan dan kekurangan orang lain.

3. Orang religius mudah melihat perbedaan. Orang spiritual mudah melihat persamaan. Karena orang religius mudah melihat perbedaan, maka orang religius membedakan dunia jadi kami dan mereka. Sedangkan orang spiritual merasa kita ini sama. Kita semua saudara. Kita sesama hamba Allah. Mudah melihat kesamaan.

4. Orang religius hanya mementingkan simbol-simbol, pakaian, ritual, dan lain-lain. Orang spiritual mementingkan esensi, hakikat, dan makna bukan hanya simbolsimbol. Orang spiritual sadar bahwa Tuhan mengutus kita kebumi untuk sebuah maksud yaitu berbuat baik. Religius adalah "caranya", Spiritual adalah "kenapa". Contohnya di sekolah kita diajarkan bagaimana caranya beribadah. Tapi tidak diajarkan kenapa kita beribadah. Sehingga pengajaran di sekolah telah kehilangan esensi/hakikat. Agama jika digambarkan seperti dua lingkaran. Lingkaran paling dalam/intinya adalah spiritualitas (why), sedangkan lingkaran paling luar adalah religiusitas (caranya). Orang religius merasa lega setelah beribadah karena merasa sudah melaksanakan kewajibannya, tetapi yang tidak spiritual, tidak mencegah dia untuk berbuat tidak baik.

5. Orang spiritual itu memperhatikan, orang religius hanya melihat. Orang spiritual itu mendengarkan, orang religius hanya mendengar. Orang religius baik dalam urusan ibadah saja. Orang spiritual baik dalam semua urusan, karena bagi orang 
spiritual semua urusan adalah ibadah. Bekerja, meng-coach bawahan dan lain-lain adalah ibadah. ${ }^{41}$

\section{Implementasi Aspek Spiritual Santri di Madrasah Diniyah Nurul Ulum}

Implementasi spiritual yang ada di Madrasah Diniyah Nurul Ulum itu penggapaiannya dengan cara, pihak madrasah menerapkan aspek- aspek klasikal yang disamakan dengan kurikulum yang ada di pondok pesantren di tanah Jawa ini. Karena asatidz di madrasah ini adalah alumni dari pesantren terkemuka di Jawa Timur, meskipun ada sebagian asatidz yang hanya alumni dari Madrasah itu sendiri. Dengan tetap mempertahankan nilai-nilai leluhur yang telah dilakukan para Wali zaman dulu. Selain itu dari data yang diperoleh oleh penulis bahwa penerapan spiritual santri di Madrasah Diniyah Nurul Ulum yaitu dengan cara mendahulukan mata pelajara Akhlaq dibandingkan dengan yang lainnya.

"Selama ini aspek spiritual yang diterapkan di madrasah ini adalah amalanamalan yang disuruh dibaca ke santri pada waktu setiap selesai sholat lima waktu. Selain berdzikir, kadang kerap kali menyuruh seluruh santri untuk selalu bertawassul kepada Nabi, Sahabat Nabi, dan guru-guru dari santri itu, dengan seringnya santri yang bertawassul maka santri akan mendapatkan perantara untuk memiliki kemampuan spiritual. ${ }^{42}$

Dalam perspektif sejarah Islam, spiritualitas telah terbukti menjadi kekuatan yang luar biasa untuk menciptakan individu-individu yang suci, memiliki integritas dan al-akblaq al-karikah yang keberadaanya bermanfaat (membawa kegembiraan) kepada orang lain. Secara sosial, spiritualitas mampu membangun masyarakat Islam mencapai puncak peradaban, mampu mencapai predikat khoiroh ummah dan keberadaannya membawa kebahagiaan untuk semua orang (rabmatan lil-alamin). ${ }^{43}$

Menurut Ustad As'ad Rofiq, beliau berpendapat bahwa:

"Penerapan aspek spiritual yang diterapkan di madrasah Diniyah Nurul Ulum yaitu dengan mengembangkan kegiatan yang bersifat bathiniyah, istilah dalam bahasa pondoknya adalah gerak batin, yaitu denganmengkokohkan agama

41 Fuad Nashori dan Rachmy Diana Muchtaram, Mengembangkan Kreatifitas dalam Prespektif Psikologi Islami (Yogyakarta: Menara Kudus Jogjakarta, 2002). Lihat juga Y.B. Mangunwijaya, Menumbubkan Sikap Religiusitas Anak-anak (Gramedia, Jakarta,1986), 15.

42 Ustd Ilham Hadi, Wawancara, Panadansari, 04 April 2018.

43 Tobroni, The Spiritual Leadership Pengefektifan Organisasi Noble Industry Melauli Prisip-prinsip Spiritual Etis (Malang: UMM Pres, 2005), 7. 
dengan melakukan amalan sunnah terutama sholat di tengah malam, dan santri disini sering di ajak melakukan sholat malam, selain itu kegiatan yang diterapkan di madrasah ini yang identik dengan aspek spiritual adalah, santri di anjurkan melakukan sholat dhuha di rumah masing masing. ${ }^{44}$

Tawassul sebagaimana di sebut diatas, sebagai salah satu kegiatan spiritual, memang pernah dibahas dalam oleh Al-Syaikh Jamil Afandi Shidqi Al-Zahawi. Ia menjelaskan bahwa yang dimaksud tawassul dengan para nabi dan orang-orang sholeh ialah menjadikan mereka sebagai sebab dan perantara dalam memohon kepada Allah SWT untuk mencapai tujuan. Pada hakikatnya Allah SWT adalah pelaku yang sebenarnya (yang mengabulkan doa). ${ }^{45}$

Ada banyak dalil yang menjelaskan keutamaan tawassul. Diantaranya adalah firman allah yang artinya sebagai berikut:

"jika mereka telah berbuat aniaya pada dirinya (berbuat dosa), lalu mereka datang kepadamu wahai Mubammad dan meminta ampunan kepada Allah, kemudian Rosul memohonkan ampuan untuk mereka, tentulah Allah yang maha menerima taubat dan yang maha penyayang akan menerima taubat mereka". (QS. Al- Nisa': 64). ${ }^{46}$

Ustadzah Muhabbahsalahsatutenagapengajar di madrasah initurutmenjelaskan:

"Pembinaan aspek spiritual yang telah diterapkan di Madrasah Diniyah Nurul Ulum yaitu sangat banyak sekali, namun yang paling sering dilakukan pembinaan untuk membentuk spiritual adalah memperbanyak melakukan ibadah sunnat, meraskan apa yang dipelajari oleh santri, peresapan atas hal yang berbau penghayatan." ${ }^{47}$

Hal diatas sama dengan apa yang penulis ketahui dari sebuah buku yang di karang oleh pasangan suami istri yaitu Danah Zohar dan Ian Marshall, dalam bukunya dijelaskan salah satu pembinaan aspek spiritual adalah rasa pengabdian dalam hidupnya. ${ }^{48}$

\footnotetext{
44 Ustad As'ad, Wawancara, Pandansari, 27 Maret 2018

${ }^{45}$ Muhyiddin Abdusshomad, Hujjah NU Akidah-Amaliab- Tradisi (Surabaya: Khalista, 2012), 104.

46 Setelah mengamati ayat ini, KH. Sirojuddin Abbas menyimpulkan bahwa orang yang yangtelah melakukan kesalahan, baik kecil ataupun besar, boleh datang kepada Rosulullah SAW, orang -orang sholeh, para guru serta orang - orang yang dekat kepada Allah untuk melakukan tawassul dalam rangka pertaubatan, dan mengharap mereka untuk memintakan ampun kepada Allah atas segala dosa yang telah dilakukan orang tersebut. (Empat Puluh Masalah Agama, Jilid I),137.

${ }^{47}$ Hasil Observasi, pada hari senin, 16 April 2018, jam 14:05

48 Danah Zohar dan Ian Marshall. SQ kecerdasan Spritual (Jakarta: Mizan Pustaka, 2007), 226
} 


\section{Faktor yang Mempengaruhi Aspek Spiritual di Madrasah Diniyah Nurul Ulum}

Faktor pendukung yang menyebabkan santri memiliki kemampuan spiritual yang mapan adalah silaturahim dan kekuatan berinteraksi dengan para guru, sekalipun sudah meninggal. Ustadz Hadi menyampaikan:

"Faktor - faktor yang dapat mendukung santri agar memiliki aspek spiritual yang tinggi, pertama, mendekatkan diri kepada Allah, karena jika kita memutuskan hubungan dengan allah maka secara otomatis kekuatan spiritual kita akan berkurang bahkan kalau terus dilakukan akan menjadi habis. Kedua, adanya penguatan tali silaturrahmi santri terhadap guru-guru sesepuh, artinya santri harus sering-sering mentawassulkan guru-gurunya, santri harus menyambung tali silaturrahmi tersebut secara dhohir dan batin. yaitu dengan mengirimkan fatihah kepada guru - guru santri, sampai tersambung ke sanad dengan kanjeng Nabi Muhammad SAW". ${ }^{49}$

Syamsuri, salah satu wali murid madrasah diniyah ini juga menyampaikan perilhal faktor yang mendukung internalisasi dan implementasi aspek spiritual, ia menyampaikan:

"Faktor yang sangat mendukung di Madrasah Diniyah Nurul Ulum yang telah mencetak santri yang memiliki kemampuan spiritual adalah materi yang di pelajari dimadrasah itu sendiri, yaitu bahwa di Madrasah Diniyah Nurul Ulum, antara mata pelajaran yang banyak disana lebih mementingkan pelajaran akhlaq, dimana, jika santri sudah mempunya akhlaq yang baik maka sangat dimungkinkan meskipun santri itu sulit mencerna pelajaran maka santri tersebut juga akan memiliki kemampuan yang sangat istimewa, yaitu dari segi kelakuan sehari-hari". ${ }^{50}$

Akhlaq, menjadi salah satu mata pelajaran penting dalam madrasah diniyah ini. Hal itu karena pandangan seluruh pengelola lembaga pendidikan, dasar interaksi manusia dengan tuhan dan manusia lainnya adalah akhlaq.

Faktor-faktor yang mempengaruhi kecerdasan spiritual menurut Agustian adalah pertama, inner value (nilai - nilai spiritual dari dalam) yang berasal dari dalam diri (suara hati), seperti: transparency (keterbukaan), responsibilitas (tanggung jawab), accountabilitas (kepercayaan), fairness (keadilan), dan sosial wareness (kepedulian sosial).

49 Ilham Hadi, Wawancar, Pandansari, 05 April 2018

50 Samsuri, Wawancara, Pandansari, 05 April 2018

114 | Tarbiyatuna: Jurnal Pendidikan Islam; Volume 12, Nomor 1, Februari 2019 p-ISSN: 2085-6539; e-ISSN: 2242-4579 
Kedua, adalah drive, yaitu dorongan dan usaha untuk mencapai kebenaran dan kebahagiaan. $^{51}$

Zohar dan Marshall mengungkapkan ada beberapa faktor yang mempengaruhi kecerdasan spiritual, yaitusel saraf otak. Otak menjadi jembatan antara kehidupan bathin dan lahiriyah kita. Ia mampu menjalankan semua ini karena bersifat kompleks, luwes, adaptif dan mampu mengorganisasikan diri. Menurut penelitian yang dilakukan pada era 1990-an dengan menggunakan MEG (Magneto, Encephalo, Graphy) membuktikan bahwa osilasi sel saraf otak pada rentang $40 \mathrm{~Hz}$ merupakan basis bagi kecerdasan spiritual. ${ }^{52}$

\section{Kesimpulan}

Penerapan aspek spiritual yang dilakukan di Madrasah Diniyah Nurul Ulum Pandansari Senduro Lumajang adalah dengan mempertahankan kurikulum klasik berupa Akhlaq sebagai dasar dari seluruh mata pelajaran. Hal tersebut diterapkan bukan hanya kepada santrinya, melainkan seluruh asatidz.

Adapun Pembinaan aspek spiritual yang diterapkan di madrasah ini ada dilakukan dengan dua hal yakni, pertama, Spiritual bathiniyah. Spiritual ini seperti riyadhih bathiniyah, yang dimaksudkan adalah santri ketika melakukan hal yang dhohir seperti sholat dan lain-lain harus disertai dengan pemikiran yang terdalam, artinya santri menghayati dengan adanya kegiatan tersebut. Kedua, Spiritual dhobiriyah seperti yang acap sekali dilakukan oleh santri setiap hari, seperti proses belajar mengajar di kelas.

Adapun faktor pendukung aspek spiritual yang ada di Madrasah Diniyah Nurul Ulum sesuai dengan apa yang telah diperoleh oleh peneliti ada tiga yang ketiganya itu merupakan kesimpulan dari semua data yang ada, ketiga faktor tesebut adalah Ada ilham atau hidayah Allah, semangat dari santri itu sendiri dan dukungan dari faktor lingkungan sekitar.

\section{Referensi}

51 Agustian, Emotional Spiritual Quotient (ESQ, 153.

52 Zohar dan Marshall. SQ kecerdasan Spritual, 65. 
Abdusshomad, Muhyiddin. 2012. Hujjah NU Akidah- Amaliah- Tradisi, Surabaya: Khalista.

Agustian, Ary Ginanjar. 2001. Rahasia Sukses Membangun Kecerdasan Emosi dan Spiritual ESQ Emotional Spiritual Quotient Berdasarkan 6 Rukun Iman dan 5 Rukun Islam, Jakarta: Arga Wijaya Persada.

Al-kumayyi, Sulaiman. 2005. Menuju hidup Sukses Kontribusi Spiritual Intelektual A A Gym dan Arifin Ilham, Semarang: Pustaka Nuun.

Chaplin, J.P. dan Kartini Kartono. 2005. Kamus Lengkap Psikologi, Jakarta: Raja Grafindo Persada.

Goleman, Daniel. 2003. Emotional Intelligence: Mengapa EQ Lebih Penting daripada IQ, Jakarta: Gramedia Pustaka Utama.

Hafidhuddin. 2003. Management Syari'ah Dalam Praktek, Jakarta: Gema Insani.

Junus, Muhammad. 1996. Terjemah Al-Quran Al-karim, Bandung: Al-Ma’arif.

Kadir, Abd. 2007. "Aspek Pendidikan Spiritual Islam: Implementasi dan Implikasi Pendidikan Islam Terhadap Pengembangan Spiritualitas Keperibadian Muslim”, Disertasi, UIN Sunan Kalijaga, Yogyakarta.

Muhyidin, Muhammad. 2007. Manajemen ESQ Power, Yogyakarta: Diva Press.

Mujib, Abdul. 2006. Rub dan Psikology. Jakarta: Prenada Media.

Nasr, Seyyed Hossein. 1975. Islam dan Nestapa Manusia Modern, Bandung: Pustaka.

Nggermanto, Agus. 2001. Quantum Quotient: Kecerdasan Quantum, Bandung: Multi Intelligence Centre.

Patton, Patricia. 2002. Emotional Quotient (EQ); Pengembangan Sukses Lebih Bermakna Makasar: Mitra Media.

Purwati, Eni dkk, 2012. Pendidikan Karakter: Menjadi Berkarakter Muslim - Muslimah Indonesia, Surabaya: Kopertais Wilaya IV.

Tobroni. 2005. The Spiritual Leadership Pengefektifan Organisasi Noble Industry Melauli Prisip-prinsip Spiritual Etis, Malang: UMM Pres.

Zohar, Danah dan Ian Marshal. 2001. SQ memanfaatkan Kecerdasan Spiritual dalam berfikir Integralistik dan Holistik untuk Memaknai Kebidupan, Bandung: Mizan. 
Zohar, Danah dan Ian Marshal. 2007. SQ kecerdasan Spritual, Jakarta: Mizan Pustaka. 